\title{
Decolourization of Direct Blue 2 by peroxidases obtained from an industrial soybean waste
}

\author{
E Miranda-Mandujano', G Moeller-Chávez ${ }^{2 *}$, O Villegas-Rosas ${ }^{3}$, Germán Buitrón ${ }^{4}$ and MA Garzón-Zúñiga ${ }^{5}$ \\ ${ }^{1}$ Universidad Nacional Autónoma de México, Postgraduate Program in Environmental Engineering, Av. Universidad \#3000, 04510, Distrito Federal México \\ ¿Universidad Politécnica del Estado de Morelos, Environmental Engineering Department, Boulevard Cuauhnáhuac \#566, \\ Col. Lomas del Texcal, Jiutepec, 62550 Morelos, México \\ ${ }^{3}$ Benemérita Universidad Autónoma de Puebla, Postgraduate Program in Environmental Science, 14 sur \#6301, \\ Jardines de San Manuel, 72570 Puebla, México \\ ${ }^{4}$ Laboratory for Research on Advanced Processes for Water Treatment, Instituto de Ingeniería, Unidad Académica Juriquilla, Universidad Nacional \\ Autónoma de México, Blvd. Juriquilla \#3001, 76230 Querétaro, México \\ ${ }^{5}$ Instituto Politécnico Nacional. Centro Interdisciplinario de Investigación para el Desarrollo Integral Regional (CIIDIR) Unidad Durango, México
}

\begin{abstract}
In this work the decolourization of Direct Blue 2 dye (DB2) using an industrial soybean waste as a source of peroxidases was studied. Temperature, $\mathrm{pH}$, amount of $\mathrm{H}_{2} \mathrm{O}_{2}$ and concentration of dye were evaluated to determine the maximum catalytic activity of the enzyme during the dye degradation process. It was observed that a temperature of $40^{\circ} \mathrm{C}$, a $\mathrm{pH}$ of 5 and a concentration of $40 \mathrm{mg} / \mathrm{L}$ for the dye in aqueous phase, play a significant role in the overall enzyme-mediated reaction. The maximum decolourization efficiency achieved under optimal conditions was $70 \% \pm 4 \%$. HPLC studies were carried out to confirm dye degradation and analyse the intermediate metabolites. The oxidation products quantified during the reaction were benzidine and 4 aminobiphenyl. Also, an increase in toxicity, determined by Vibrio fisheri, was observed after the enzymatic oxidation of the dye. Results suggest that the oxidation of DB2 with peroxidases can be recommended as a pretreatment step before a conventional treatment process.
\end{abstract}

Keywords: decolourization, Direct Blue 2, industrial waste, soybean peroxidase, oxidation, toxicity

\section{INTRODUCTION}

The textile industry is one of the major sources of water pollution due to the volume and composition of effluents produced, which are typically characterized as having a high temperature, $\mathrm{pH}$ and colour (Srinivasan and Viraraghavan, 2010; Kumar et al., 2007). The environmental impact caused by this industrial sector is varied, but colour is the first sign of contamination observed in effluents, with concentrations as high as $1 \mathrm{~g} / \mathrm{L}$ (Kaushik and Malik, 2009). Azo dyes constitute the most important family of industrial dyes. They are recalcitrant and xenobiotic compounds characterized by the presence of one or more azo groups $(-\mathrm{N}=\mathrm{N}-)$, that make them extremely difficult to eliminate by biodegradative processes (Melgoza and Buitrón, 2004). It has been reported that many of these dyes generate acute and chronic toxicity in ecosystems (Dallago et al., 2005). It is well known that the amount of dye wasted in the effluents depends on the application type used, varying from $2 \%$ to $50 \%$, which is then discharged (in the absence of adequate previous treatment) into water bodies (Dos Santos et al., 2007).

Elimination of azo dyes from industrial wastewater is an important issue in wastewater treatment. It has been demonstrated that a single process is not enough for the efficient degradation and mineralization of the dyes and their byproducts (Supaka et al., 2004). Biological processes have been considered as an effective alternative for the

\footnotetext{
To whom all correspondence should be addressed.

喵 +52 7772293533

e-mail: gmoeller@upemor.edu.mx
}

Received 22 November 2016; accepted in revised form 12 March 2018 treatment of coloured effluents (Rai et al., 2005), but the need for acclimation, high hydraulic residence times, and the recalcitrant nature of some dyes, as well as the use of additives that improve the fixation of the dyes, constitute the main limitations encountered for stable operation (Hai et al., 2007). Physical, chemical and advanced oxidation processes, such as ozonation, Fenton's reagents and photo-Fenton, have shown good capacity to decolourize these effluents by chemical oxidation, but high investment and operating costs have limited their application (Verma et al., 2012; Prato and Buitron, 2012; Gutowska et al., 2007).

Recently, studies have been successfully conducted using enzymes with peroxidase activity in the oxidative degradation of coloured compounds, when this cannot be achieved using conventional treatment processes (Matto and Husain, 2007; Mohan et al., 2005). Enzymes with peroxidase activity can specifically react with organic pollutants and remove them by precipitation or the cleavage of the aromatic ring structure, transforming them into other products (Husain, 2010). The catalytic action of enzymes is generally very efficient and selective due to their higher reaction rates and greater stereo-specificity. They can catalyse reactions at relatively low temperature and in the entire aqueous phase $\mathrm{pH}$ range, and with lower probability of inhibition caused by substances that might be toxic to microorganisms, and lower cost and retention time, making this process more attractive than conventional treatment methods (Kalsoom et al., 2013; Boscolo et al., 2006).

Peroxidases that have been used for treatment of dyes include horseradish peroxidase (HRP), lignin peroxidase $(\mathrm{LiP})$, manganese peroxidase $(\mathrm{MnP})$ and a number of the other peroxidases obtained mainly from plants, vegetables and microorganisms. HRP is the most often used, due to its ability 
to efficiently cleave aromatic compounds in the presence of peroxide, despite the high costs of its production (Boucherit et al., 2013; Neves et al., 2012; Mohan et al., 2005). Several investigations have reported the use of peroxidases for the removal of azo dyes in aqueous phase, obtaining percentages of decolourization ranging from 50 to $90 \%$ using different operating conditions (Nouren and Nawaz, 2015; Silva et al., 2012; Marchis et al., 2011).

In the literature several studies employing soybean peroxidases (SBP) for the decolouration of azo dyes can be found. Calza et al. (2016), applied an enzymatic and photocatalytic treatment with SBP for the removal of three common dyes (Orange I, Orange II, and Methyl Orange), as well as the anticonvulsant drug carbamazepine, from aqueous solutions. SBP was extracted from hulls of fresh soybean (Glycine max) seeds and successively purified and immobilized on silica monoliths. All the dyes were completely removed within $2 \mathrm{~h}$, in the presence of immobilized SBP. Chiong et al. (2016) obtained soybean peroxidase and Luffa acutangula (luffa) peroxidase, extracted from bio-wastes of soybean hulls and luffa skin peels, respectively, for enzymatic degradation of azo dye methyl orange from liquid effluents. SBP demonstrated a maximum dye decolourization efficiency of $81.4 \%$ at $30 \mathrm{mg} / \mathrm{L}$. Ali et al. (2013), investigated the enzymatic degradation of an azo dye (Crystal Ponceau 6R, CP6R) using commercially available SBP enzyme. Under optimized conditions, $40 \mathrm{mg} / \mathrm{L}$ dye solution was completely degraded in $1 \mathrm{~min}$ in the presence of $\mathrm{H}_{2} \mathrm{O}_{2}$ and a redox mediator. Dye degradation was also confirmed using HPLC and TOC analyses, which showed that most of the dye was mineralized in the process. Silva et al. (2012) evaluated the potential use of soybean peroxidase in the decolourization of reactive textile dye Remazol Brilliant Blue $\mathrm{R}$ (RBBR) and its synthetic effluent. The maximum removal of RBBR (86\%) was obtained after $13 \mathrm{~min}$ of reaction and at an RBBR concentration of $40 \mathrm{mg} / \mathrm{L}$. Kalsoom et al. (2013), used soybean peroxidase to efficiently degrade Trypan Blue, a diazo dye. The soybean peroxidase (SBP) used in this study was obtained from a commercial supplier and was used as supplied. Studies carried out at different concentrations of the dye (10,20, 40 and $80 \mathrm{mg} / \mathrm{L}$ ) yielded a maximum decolourisation efficiency of $90 \%$ in the best operating conditions.

Despite the variety of sources of peroxidases, to the best of our knowledge, there are no previous reports related to the recovery of peroxidases from an industrial waste and its application for colour removal. In this work, we present results obtained from a partially purified extract from an industrial soybean waste (okara) and its application in the decolourization of the Direct Blue 2 dye (DB2), widely used in the textile industry for dyeing denim. Effects of different parameters like $\mathrm{pH}$, temperature, reaction time, $\mathrm{H}_{2} \mathrm{O}_{2}$ dosage and dye concentration were tested in order to optimize the dye degradation. The toxicity before and after the enzymatic treatment was evaluated by Vibrio fisheri as a bio-indicator. To identify the principal products or intermediates of the dye oxidation HPLC was utilized.

\section{MATERIALS AND METHODS}

\section{Crude extract}

The crude extract was prepared from waste (okara) generated by the processing of soybeans for the production of a commercial juice. $200 \mathrm{~g}$ of okara were homogenized in $2 \mathrm{~L}$ of deionized water for $15 \mathrm{~h}$ at $4^{\circ} \mathrm{C}$. Then the mixture was centrifuged at $15000 \times g$ for $20 \mathrm{~min}$ at $4^{\circ} \mathrm{C}$ (Thermo Scientific Sorval Lynx 4000). The supernatant was dialyzed using 12 $\mathrm{kD}$ membrane with a buffer of sodium acetate/acetic acid $(1 / 50)$, up to a $10 \mathrm{mM}$ concentration at $\mathrm{pH} 4.5$ and $4^{\circ} \mathrm{C}$. The dialyzed enzyme extract was stored $\left(4^{\circ} \mathrm{C}\right)$ and used for further purification.

\section{Peroxidase activity and protein measurements}

The peroxidase activity was determined by the 4-aminoantipyrine method (Bhunia et al., 2001). This colorimetric estimation uses phenol and $\mathrm{H}_{2} \mathrm{O}_{2}$ as substrates and 4 -aminoantipyrine $\left(\mathrm{Am}-\mathrm{NH}_{2}\right)$ as chromogen. The assay was performed at $25^{\circ} \mathrm{C}$; the reaction mixture contained phosphate buffer (0.1 M, pH 7.4), phenol (0.2 M), $\mathrm{H}_{2} \mathrm{O}_{2}\left(2 \times 10^{-3} \mathrm{M}\right)$, 4-aminoantipirine $\left(4.8 \times 10^{-2} \mathrm{M}\right)$ and enzymatic extract. The consumption rate was estimated measuring the absorbance of coloured product at $510 \mathrm{~nm}$ using a UV-vis spectrophotometer (Agilent Technologies Cary 60). A parallel control containing all the ingredients of the assay, except the enzyme, was used as a blank and those without substrate were used as a control. One unit of peroxidase activity (U) represents the amount of enzyme catalysing the oxidation of $1 \mu \mathrm{mol}$ of substrate during $1 \mathrm{~min}$.

Total protein concentration was measured with the BioRad Bradford protein estimation kit using the microassay procedure with bovine serum albumin as standard protein (Agostini et al., 1997).

\section{Purification of peroxidase}

The partial peroxidase purification was conducted by ion exchange chromatography (IEC) using a column of DEAE53cellulose $(2.5 \times 15 \mathrm{~cm})$ (Himmelhoch, 1971). The matrix was equilibrated with $0.2 \mathrm{mM}$ and $0.01 \mathrm{mM}$ phosphate buffer $(\mathrm{pH}$ 7.4 and $4^{\circ} \mathrm{C}$ ). $700 \mathrm{~mL}$ of crude extract were fed to the column at a continuous flow rate of $3 \mathrm{~mL} / \mathrm{min}$. The bound protein was eluted using $100 \mathrm{~mL}$ of $1 \mathrm{M} \mathrm{NaCl}$. 20 fractions of $5 \mathrm{~mL}$ were collected throughout the elusion. The fractions were also analysed using UV-visible spectroscopy at $280 \mathrm{~nm}$; enzyme activity and protein concentration were analysed with the previously described methodology. Fractions containing peroxidase activity were then stored at $4^{\circ} \mathrm{C}$ until use.

\section{Dye and decolourization studies}

The dye used in this research was DB2 (Direct Blue 2) donated by a textile industry in México. Some of the chemical properties as well as the structure are presented in Table 1. The aqueous solution of dye was prepared before experiments by dissolving the necessary amount of dye in deionized water.

Decolourization studies were performed on a digital hotplate/stirrer with 9 sites (Dataplate Serie 730 PMC), using $50 \mathrm{~mL}$ Erlenmeyer flasks with a working volume of $30 \mathrm{~mL}$. The reaction mixture was carried out using a magnetic stirrer at 150 $\mathrm{r} / \mathrm{min}$. A sample was taken each $10 \mathrm{~min}$ and then centrifuged at $3800 \times g$ for 5 min to estimate the residual dye concentration in the aqueous phase. Decolourization percentage of the dye was assessed by changes in absorbance at $576 \mathrm{~nm}$, using a UV-vis spectrophotometer (Perkin-Elmer UV-25 USA). Dye removal percentage was calculated by:

Percentage of decolourization: $\left[1-\frac{C_{t}}{C_{i}}\right] \times 100$ 


\begin{tabular}{|l|l|}
\hline \multicolumn{2}{|c|}{$\begin{array}{c}\text { TABLE 1 } \\
\text { Characteristics of DB2 }\end{array}$} \\
\hline Name & Direct Blue 2 \\
\hline Colour index & 22590 \\
\hline Molecular formula & $\mathrm{C}_{32} \mathrm{H}_{21} \mathrm{~N}_{6} \mathrm{Na}_{3} \mathrm{O}_{11} \mathrm{~S}_{3}$ \\
\hline Molecular weight & $830.71 \mathrm{~g} / \mathrm{mol}$ \\
\hline Water solubility & $45 \mathrm{~g} / \mathrm{L}\left(25^{\circ} \mathrm{C}\right)$ \\
\hline $\begin{array}{l}\text { Molecular } \\
\text { structure }\end{array}$ & \\
\hline
\end{tabular}

Where, $C_{i}$ is the initial concentration of the sample and $C_{t}$ is the concentration at a given reaction time.

Subsequent series of experiments were performed varying $\mathrm{pH}$ (from 3.5 to 7.5 ), temperature (from 25 to $50^{\circ} \mathrm{C}$ ), $\mathrm{H}_{2} \mathrm{O}_{2}$ concentration (10 to $500 \mu \mathrm{mol} / \mathrm{L}$ ) and dye concentration (from 10 to $60 \mathrm{mg} / \mathrm{L}$ ) to determinate the best conditions for dye removal.

Control experiments for each test were carried out using medium with dye and without enzyme. The experiments were performed in triplicate, and mean and standard deviation were calculated accordingly.

\section{HPLC}

The HPLC analyses were performed using a liquid chromatographic system (Thermo Surveyor, auto sampler and diode array detector-DAD). A column C18-Ar ACE $(150 \times 4.5 \mathrm{~mm})$ was used for chromatographic separation. The sample was filtered through membranes of $0.2 \mu \mathrm{m}$, before injection into the chromatograph. A volume of $30 \mu \mathrm{L}$ of the sample was injected; methanol/acetonitrile/phosphoric acid $0.1 \%$ was used as mobile phase at a flow rate $1 \mathrm{~mL} / \mathrm{min}$.

\section{Toxicity test}

The Microtox toxicity assays were carried out with Vibrio fischeri (Microtox Azure Ambiental). The reagent is a lyophilized preparation from a specially selected strain of the marine bacteria Vibrio fischeri (formerly known as Photobacterium phosphoreum, NRRL number B-11177). Phenol was used as the reference compound in the toxicity assays $\left(100 \mathrm{mg} / \mathrm{L}\right.$ phenol; $\left.\mathrm{TU}=3 ; \mathrm{EC}_{50}=23 \mathrm{mg} / \mathrm{L}\right)$. The toxicity assays were conducted on samples at the beginning and end of the

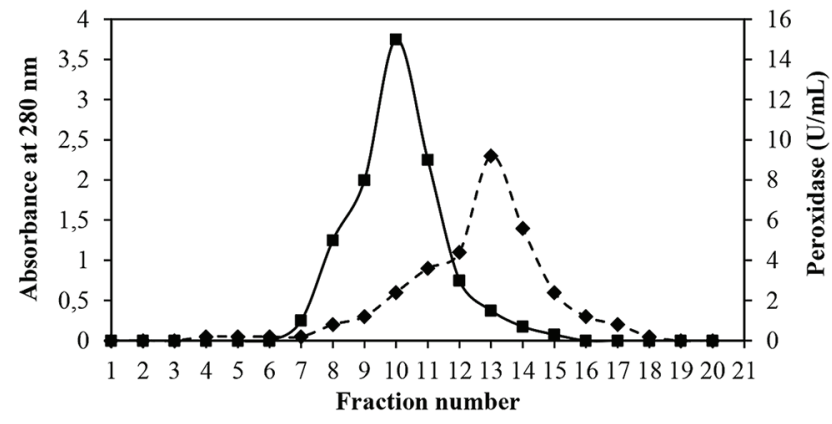

Figure 1

Anion-exchange chromatography of enzymatic crude: (ロ) peroxidase $\mathrm{U} / \mathrm{mL},(\diamond)$ absorbance at $280 \mathrm{~nm}$ tests to obtain the $\mathrm{EC}_{50^{\circ}}$. Toxicity was expressed in toxicity units (TU), where $\mathrm{TU}=100 / \mathrm{EC}_{50}$

\section{RESULTS AND DISCUSSION}

\section{Purification of peroxidase}

Peroxidase activity of the crude extract was $2.8 \mathrm{U} / \mathrm{mL}$, which is in the range of the reported values obtained from the extract of horseradish root (Gholami et al., 2011; Mohan et al., 2005), ranging from 2.36 to $2.94 \mathrm{U} / \mathrm{mL}$. However, experimental data from this study showed that when partial purification by chromatography using a column of DEAE53-cellulose is applied, the peroxidase activity can be increased to $15 \pm 5 \mathrm{U} / \mathrm{mL}$.

Using IEC as a primary purification step increased the degree of enzyme purification with an overall recovery of $45 \%$ and specific activity of $22.7 \mathrm{U} / \mathrm{mg}$, obtaining a value of $\mathrm{RZ}\left(\mathrm{Abs}_{403 \mathrm{~nm}} / \mathrm{Abs}_{280 \mathrm{~nm}}\right)=1.1$ for the fraction with the highest enzymatic activity. Figure 1 shows the elusion profile of the enzyme in the DEAE53-cellulose column. Similar results have been reported in the literature where peroxidases were obtained from plants and vegetables by conventional methods. Shaffiqu et al. (2002) found peroxidases with high enzymatic activity using plants I. palmata and S. spontaneum collected in Trivandrum, India; the crude extract was purified by ion exchange and gel chromatography to obtain specific activities of $34.7 \mathrm{U} / \mathrm{mg}$ of protein with a purification factor of $77.8 \%$. Gholami et al. (2011) obtained an extract from horseradish root of a local plant of Iran with enzymatic activities of $2.36 \mathrm{U} / \mathrm{mL}$, employing ammonium sulfate precipitations as a first-step partial purification to increase peroxidase activity $18.5 \mathrm{U} / \mathrm{mL}$. Boucherit et al. (2013) used local zucchini of Algeria to obtain peroxidases using the acetone precipitation method, obtaining enzymatic activities of $2.19 \mathrm{U} / \mathrm{mL}$ and a purification factor of 1.34 .

\section{Contact time effect}

The decolourization efficiency of DB2 as a function of the enzyme contact time was determined by employing the enzyme at the highest catalytic activity. DB2 was used as the substrate. The enzymatic reactions were performed at $25^{\circ} \mathrm{C}$ using $60 \mathrm{mg} \mathrm{DB} 2 / \mathrm{L}$ and maintaining $\mathrm{pH}$ at $6.5,200 \mu \mathrm{mol} / \mathrm{L}$ of $\mathrm{H} 2 \mathrm{O} 2$, extracted enzyme and $240 \mathrm{~min}$ of reaction time. Dye removal attained a maximal value of $50 \% \pm 1.95$. After $200 \mathrm{~min}$ no more removal was observed and $200 \mathrm{~min}$ was used as the reaction time for subsequent experiments (Fig. 2). Similar decolourization percentages have been observed in

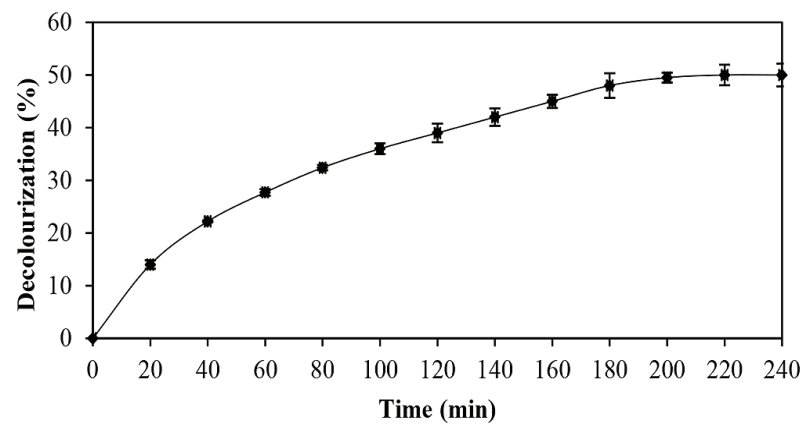

Figure 2

The impact of reaction time on the decolourization of DB2 in presence of peroxidase enzyme 
other studies (Silva et al., 2012; Mohan et al., 2005; Shaffiqu et al., 2002). It has been reported that the decolourization time showed a relationship with the chemical structure of the dyes. In general, colourants with simple structures and low molecular weights usually exhibited higher rates of dye removal, whereas dye removal is less effective with highly substituted and high molecular weight dyes (Chen et al. 2003).

\section{Effect of $\mathrm{pH}$ and temperature}

Studies of $\mathrm{pH}$ and temperature were carried out keeping constant the concentration of DB2, reaction time, enzyme and peroxide, at $60 \mathrm{mg} / \mathrm{L}, 200 \mathrm{~min}, 15 \mathrm{U} / \mathrm{mL}$ and $200 \mu \mathrm{mol} / \mathrm{L}$ respectively. The $\mathrm{pH}$ was varied between 3.0 to 7.5 and the temperature from 25 to $60^{\circ} \mathrm{C}$. The enzymatic activity of peroxidase enzyme presented a maximal value at $\mathrm{pH} 5.5$ (Fig. 3A). The highest dye removal rate was found at $\mathrm{pH}$ 5.5, reaching up to $64 \% \pm 1.5$. Previous studies have reported that the optimum $\mathrm{pH}$ for the decolourization of the diazo dyes by soybean peroxidases is 4 (Kalsoom et al., 2013). Also, for the decolourization of Remazol Blue by HRP, a pH of 2.5 was proposed (Bhunia et al., 2001). This dependence on $\mathrm{pH}$ can be explained by the mechanism of the catalytic cycle of peroxidases (Muhammad and Salman, 2012), that involves the formation of two intermediate compounds, namely Compound I and Compound II, where SH indicates a generic substrate, according to the following reactions:

Peroxidase $+\mathrm{H}_{2} \mathrm{O}_{2} \rightarrow$ Compound $\mathrm{I}+\mathrm{H}_{2} \mathrm{O}$

Compound $\mathrm{I}+\mathrm{SH} \rightarrow$ Compound $\mathrm{II}+\mathrm{S}$

Compound II $+\mathrm{SH} \rightarrow$ Peroxidase $+\mathrm{S}+\mathrm{H}_{2} \mathrm{O}$

In acidic conditions and in the presence of hydrogen bonding between heme $/ \mathrm{H}_{2} \mathrm{O}_{2}$, distal histidine and arginine side chain, the formation of Compound I is favoured. The rates of the substrate oxidation processes in Steps 2 and 3 have been found to be dependent on the protonated state of Compound I (Laurenti et al. 2003), explaining why soybean peroxidases showed better degradation performance in acidic media.

It was found that when increasing the temperature from 25 to $40^{\circ} \mathrm{C}$, the decolourization percentages increased to $56 \%$ (Fig. 3B). Nevertheless, beyond $40^{\circ} \mathrm{C}$ no more improvement was observed and at $60^{\circ} \mathrm{C}$ only $43 \%$ of decolourization was reached. Similar data have been described previously. In the degradation of direct azo by Curcurbita pepo peroxidases the optimal temperature was $40^{\circ} \mathrm{C}$ (Boucherit et al., 2013), and $30-35^{\circ} \mathrm{C}$ for the treatment of Tripan blue by SBP. It has been reported that soybean peroxidase is a thermally stable enzyme at $90.5^{\circ} \mathrm{C}$ and pH 8 (Kalsoom et al., 2013).

\section{Effect of $\mathrm{H}_{2} \mathrm{O}_{2}$ concentration}

Hydrogen peroxide acts as a co-substrate to activate the enzymatic activity of peroxidase. That promotes the catalytic cycle of peroxidases, where initially the native enzyme is oxidized to form an intermediate enzyme, which accepts the aromatic compounds to oxidize them to a free radical form. The excess of this reagent in the reaction inhibits the enzyme activity and, when added in low quantities, limits the reaction rate (Silva et al., 2012; Wu et al., 1994). The $\mathrm{H}_{2} \mathrm{O}_{2}$ doses varied between 50 and $300 \mu \mathrm{mol} / \mathrm{L}$, and it was found that $200 \mu \mathrm{mol}$ $\mathrm{H}_{2} \mathrm{O}_{2} / \mathrm{L}$ promoted the highest enzyme activity and achieving decolourization percentage of $57 \% \pm 2 \%$ (Fig. 3C). However, no greater differences in the enzymatic activity were found with
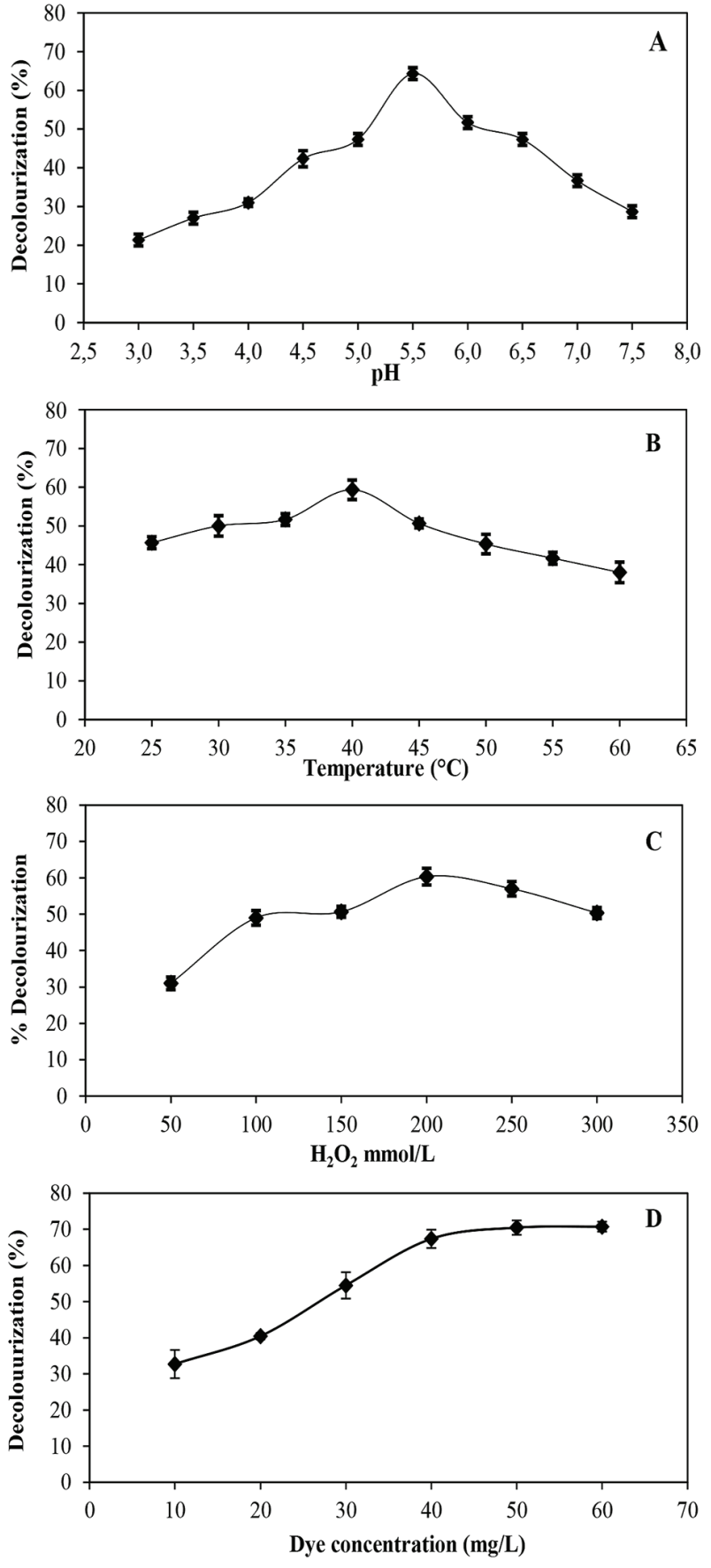

Figure 3

Effect of $(A) p H(B)$ Temperature $\left({ }^{\circ} \mathrm{C}\right)(C) \mathrm{H}_{2} \mathrm{O}_{2}(\mathrm{mmol} / \mathrm{L})$ and $(D)$ Dye concentration $(\mathrm{mg} / \mathrm{L})$ on the decolourization of DB2 in presence of peroxidase enzyme

the $100,150.250$ and $300 \mu \mathrm{mol} / \mathrm{L}$ doses, having an average decolourization percentage of $51.7 \% \pm 1.92$. Concentrations less than 50 showed a decrease in reaction rate. Similar results have been reported employing $100 \mu \mathrm{mol} / \mathrm{L}$ of $\mathrm{H}_{2} \mathrm{O}_{2}$, achieving decolourization of $57 \%$ by turnip peroxidase (Silva et al., 2012).

\section{Effect of dye concentration}

To evaluate the effect of the dye concentration (from 10 to $60 \mathrm{mg} / \mathrm{L}$ ) on decolourization percentage, $\mathrm{pH}(5.5)$, 
temperature $\left(40^{\circ} \mathrm{C}\right)$, enzyme concentration $(15 \mathrm{U} / \mathrm{mL})$, peroxide concentration $(200 \mu \mathrm{mol} / \mathrm{L})$ and reaction time $(200$ min) were maintained. It was found that from 10 to $30 \mathrm{mg}$ DB2/L, the decolourization percentage increased steadily. The highest percentage of decolourization (70\%) was achieved for concentrations higher than $40 \mathrm{mg} / \mathrm{L}$ (Fig. 3D). Similar results were obtained with other peroxidases where the initial decolourization rate increased with increasing dye concentration (Boucherit et al., 2013; Silva et al., 2012; Alam et al., 2009). The concentration of the substrate present in the aqueous phase has a significant influence on any enzymemediated reaction. If the enzyme concentration is kept constant and the substrate concentration is gradually increased, the reaction will increase until it reaches its maximum enzyme activity; after obtaining the equilibrium state any further addition of the substrate will not change the rate of reaction (Mohan et al., 2005).

The UV-visible absorbance spectra of $40 \mathrm{mg} \mathrm{DB} 2 / \mathrm{L}$, before and after enzymatic treatment under optimum conditions, are shown in Fig. 4. The spectrum exhibits a main peak with a maximum absorbance at $576 \mathrm{~nm}$. The diminution in the peaks of the dye took place due to the removal of dyes by precipitation or the cleavage of the aromatic ring structure transforming them into other products after treatment with partially purified peroxidase. It could be supposed that azo bonds $(-\mathrm{N}=\mathrm{N}-)$ of characteristic conjugated chromophores in azo dye molecules were broken (Wang et al., 2009). However, some extra peaks appeared in the treated solution at 212 and $265 \mathrm{~nm}$, probably resulting from the absorbance of metabolites or degraded fragments of the dye molecule (Boucherit et al., 2013).

In our study the enzyme concentration was not varied. The maximum enzymatic activity obtained in this work was $15 \mathrm{U} / \mathrm{mL}$, achieving $70 \%$ decolourization. Furthermore, in previous studies it was found that an increase in decolourization percentage of only $4 \%$ was achieved when the enzymatic activity was increased from 14.88 to $29 \mathrm{U} / \mathrm{mL}$ (Boucherit et al., 2013; De Souza et al., 2007).

\section{Metabolic by-products}

The samples were analysed with the HPLC technique to identify the decolourization products in the enzymatic treatment. Control experiments were carried out using dye without treatment. The peak with retention time of $4.2 \mathrm{~min}$ was identified as the DB2. After enzymatic treatment the DB2 was reduced and two new peaks corresponding to benzidine and 4 -aminobiphenyl (retention times of 1.5 and $7.2 \mathrm{~min}$ )

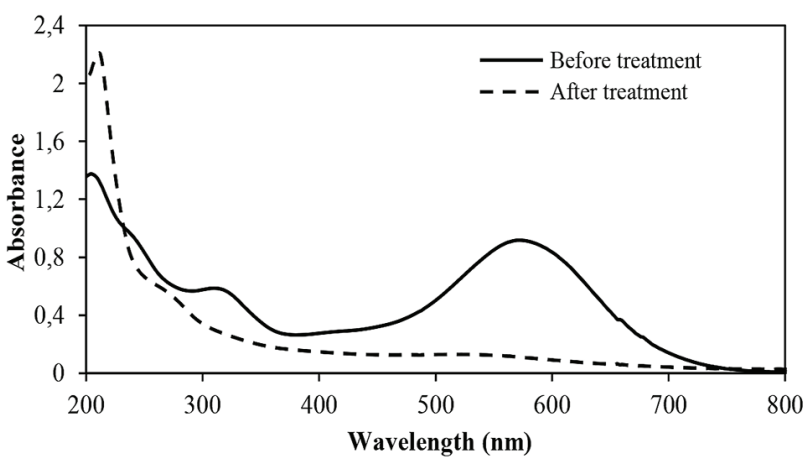

Figure 4

UV-vis spectra of DB2 at $40 \mathrm{mg} / \mathrm{L}$ before and after enzymatic treatment were observed. These compounds have been reported as DB2 by-products (Bafana et al., 2007; Golka et al., 2004). According to the stoichiometry of the reaction, only $20 \%$ of benzidine and $10 \%$ of 4 -aminobifenyl were recovered from the degradation of DB2 (Fig. 5). That may be due to the parallel production of other compounds, which are generated by different pathways of degradation or by the natural degradation of intermediaries. Alternatively, these products are not final products, so continue to degrade; or there are other ways of generating other or more degradation products, which were not studied in this research.

\section{Toxicity test}

A toxicity study of the effluent after the enzymatic treatment was carried out to evaluate whether the reaction products would be more toxic than the original dye. Controls such as enzyme, peroxide and acids were tested to take into account their influence. It was concluded that those compounds do not increase the toxicity. Table 2 shows the toxicity results obtained using Vibrio fischeri at 40, 50 and $60 \mathrm{mg} \mathrm{DB} 2 / \mathrm{L}$. The toxicity for the non-treated dye was $4.4 \mathrm{TU}$, but after treatment the toxicity increased to 17 . The toxicity increase can be attributed to the formation of toxic metabolites as benzidine and 4-aminobifenyl. Silva et al. (2012) reported an increase in acute toxicity after enzymatic treatment of Reactive Blue 21 using $L$. sitiva. They attributed the increase of the toxicity to the formation of metabolites that are more toxic than the parent molecule. The toxicity of this effluent can be eliminated by a combination of biological processes in which the microbial consortia could degrade the byproducts formed in the enzymatic step.

TABLE 2

Acute toxicity test with Vibrio fisheri, before and after 200 min of enzymatic treatment at concentrations of 40,50 and $60 \mathrm{mg} / \mathrm{L}$

\begin{tabular}{|l|c|c|}
\hline Sample & $\mathrm{CE}_{50}(\%)$ & TU \\
\hline Dye & 22.29 & 4.48 \\
\hline Effluent $40 \mathrm{mg} / \mathrm{L}$ & 6.24 & 16.02 \\
\hline Effluent $50 \mathrm{mg} / \mathrm{L}$ & 5.46 & 18.31 \\
\hline Effluent $60 \mathrm{mg} / \mathrm{L}$ & 5.6 & 17.85 \\
\hline
\end{tabular}

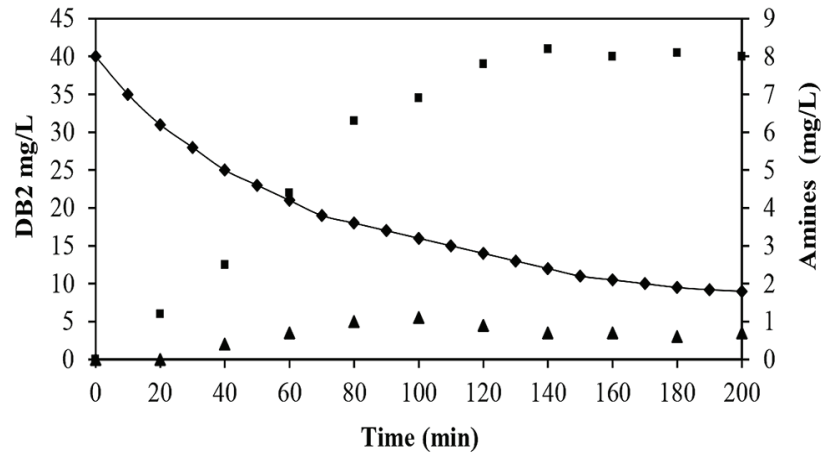

Figure 5

Profile of enzymatic oxidation of DB2 and by-products formation: DB2; (₫) Benzidine; (ム) 4-aminobiphenyl 


\section{CONCLUSION}

The experimental results obtained in this research showed the effectiveness of using an industrial waste from soybean to obtain enzymes with peroxidase activity, and its application for the decolourization of DB2. In the experimental tests the data reveals that the performance of a reaction catalysed by partially purified peroxidase for dye removal depends upon the reaction time, temperature, $\mathrm{pH}$ and dye concentration, with all of these being key factors that affect the rate of oxidation. With the best operating conditions, it was possible to achieve $70 \% \pm 4 \%$ decolourization for dye concentrations higher than $40 \mathrm{mg} / \mathrm{L}$ ( $\mathrm{pH} 5.5,40^{\circ} \mathrm{C}, 200 \mu \mathrm{mol} \mathrm{H}_{2} \mathrm{O}_{2} / \mathrm{L}$ ). Benzidine and 4 -aminobiphenyl were identified as the main by-products of the enzymatic degradation of DB2. An increase in toxicity after enzymatic treatment of the DB2 was observed and was attributed to the formation of aromatic amines. Based on these findings, it is concluded that the enzymatic treatment can be used as a previous step (pre-treatment) to conventional processes, representing an important step to facilitate the mineralization of textile dyes.

\section{ACKNOWLEDGEMENTS}

The authors would like to acknowledge CONACyT, UNAM, UNILEVER, IMTA, BUAP and UPEMOR for supporting this work.

\section{REFERENCES}

AGOSTINI E, MEDINA MJ, SILVIA R, FORCHETTI MD and TIGIER $\mathrm{H}$ (1997) Properties of anionic peroxidase isoenzymes from turnip (Brassica napus L.) roots. J. Agric. Food Chem. 45 (3) 596-598. http://pubs.acs.org/doi/abs/10.1021/jf960259u

ALAM MZ, MANSOR MF and JALAL KC (2009) Optimization of decolorization of methylene blue by lignin peroxidase enzyme produced from sewage sludge with Phanerocheate chrysosporium. J. Hazardous Mater. 162 (2-3) 708-715. https://doi.org/10.1016/j. jhazmat.2008.05.085

ALI L, ALGAITHI R, HABIB HM, SOUKA U, RAUF MA and ASHRAF SS (2013) Soybean peroxidase-mediated degradation of an azo dye - a detailed mechanistic study. BMC Biochem. 1435. https://doi.org/10.1186/1471-2091-14-35

BAFANA A, SARAVANA DS, KRISHNAMURTHI K and CHAKRABARTI T (2007) Kinetics of decolourisation and biotransformation of direct black 38 by $C$. hominis and $P$. stutzeri. Appl. Microbiol. Biotechnol. 74 (5) 1145-1152. https://doi. org/10.1007/s00253-006-0751-5

BHUNIA A, DURANI S AND WANGIKAR PP (2001) Horseradish peroxidase catalyzed degradation of industrially important dyes. Biotechnol. Bioeng. 72 (5) 562-567. http://doi.org/10.1002/10970290(20010305)72:5<562::AID-BIT1020>3.0.CO;2-S

BOSCOLO B, LAURENTI E and GHIBAUDI E (2006) ESR spectroscopy investigation of the denaturation process of soybean peroxidase induced by guanidine hydrochloride, DMSO or heat. Protein J. 25 (6) 379-390. https://doi.org/10.1007/ s10930-006-9024-5

BOUCHERIT N, ABOUSEOUD M and ADOUR L (2013) Degradation of direct azo dye by Cucurbita pepo free and immobilized peroxidase. J. Environ. Sci. 25 (6) 1235-1244. https://doi. org/10.1016/S1001-0742(12)60102-8

CALZA P, ZACCHIGNA D and LAURENTI E (2016) Degradation of orange dyes and carbamazepine by soybean peroxidase immobilized on silica monoliths and titanium dioxide. Environ. Sci. Pollut. Res. 23 (23) 23742-23749. https://doi.org/10.1007/ s11356-016-7399-1

CHEN KC, WU JY, LIOU DJ and HWANG SCJ (2003) Decolorization of the textile dyes by newly isolated bacterial strains. J. Biotechnol.
101 (1) 57-68. https://doi.org/10.1016/S0168-1656(02)00303-6 CHIONG T, YON LAU S, HONG LEK Z, YEW KOH B and DANQUAH KM (2016) Enzymatic treatment of methyl orange dye in synthetic wastewater by plant-based peroxidase enzymes. J. Environ. Chem. Eng. 4 (2) 2500-2509. https://doi.org/10.1016/j. jece.2016.04.030

DALLAGO RM, SMANIOTTO A and OLIVEIRA LCA (2005) Solid waste from tanneries as adsorbent for the removal of dyes in aqueous medium. Quim. Nova 28 (3) 433-437. http://dx.doi. org/10.1590/S0100-40422005000300013

DE SOUZA SM, FORGIARINI E and DE SOUZA AAU (2007) Toxicity of textile dyes and their degradation by the enzyme horseradish peroxidase (HRP). J. Hazardous Mater. 147 (3) 1073-1078. https:// doi.org/10.1016/j.jhazmat.2007.06.003

DOS SANTOS AB, CERVANTES FJ and VAN LIER JB (2007) Review paper on current technologies for decolourisation of textile wastewaters: Perspectives for anaerobic biotechnology. Bioresour. Technol. 98 (12) 2369-2385. https://doi.org/10.1016/j. biortech.2006.11.013

GHOLAMI BF, HOSSEIN MA, NASSERI S, ALI FM, NABIZADEH R and ALIMOHAMMADI M (2011) Enzymatic treatment and detoxification of Acid Orange 7 from textile wastewater. Appl. Biochem. Biotechnol. 165 (5-6) 1274-1284. https://doi.org/10.1007/ s12010-011-9345-5

GOLKA K, KOPPS S and MYSLAK ZW (2004) Carcinogenicity of azo colorants: influence of solubility and bioavailability. Toxicol. Lett. 151 (1) 203-210. https://doi.org/10.1016/j.toxlet.2003.11.016 GUTOWSKA A, KALUZNA CJ and JOZWIAK WK (2007) Degradation mechanism of Reactive Orange 113 dye by $\mathrm{H}_{2} \mathrm{O}_{2} / \mathrm{Fe}^{2+}$ and ozone in aqueous solution. Dyes Pigm. 74 (1) 41-46. https://doi. org/10.1016/j.dyepig.2006.01.008

HAI FI, YAMAMOTO K and FUKUSHI K (2007) Hybrid treatment systems for dye wastewater. Crit. Rev. Environ. Sci. Technol. 37 (4) 315-377. http://dx.doi.org/10.1080/10643380601174723

HIMMELHOCH SR (1971) Chromatography of proteins on ionexchange adsorbents. Methods Enzymol. 22 273-286. https://doi. org/10.1016/0076-6879(71)22028-0

HUSAIN Q (2010) Peroxidase mediated decolorization and remediation of wastewater containing industrial dyes: a review. Rev. Environ. Sci. Bio/Technol. 9 (2) 117-140. https://doi. org/10.1007/s11157-009-9184-9

KALSOOM U, SALMAN AS, MEETANI MA, RAUF MA and NAWAZ BH (2013) Mechanistic study of a diazo dye degradation by soybean peroxidase. Chem. Cent. J. 7 (1) 1-10. https://doi. org/10.1186/1752-153X-7-93

KAUSHIK P and MALIK A (2009) Fungal dye decolorization: Recent advances and future potential. Environ. Int. 35 (1) 127-141. https:// doi.org/10.1016/j.envint.2008.05.010

KUMAR P, PRASAD B, MISHRA IM and CHAND S (2007) Catalytic thermal treatment of desizing wastewaters. J. Hazardous Mater. 149 (1) 26-34. https://doi.org/10.1016/j.jhazmat.2007.03.051

LAURENTI E, GHIBAUDI E, ARDISSONE S and FERRARI RP (2003) Oxidation of 2,4- dichlorophenol catalyzed by horseradish peroxidase: characterization of the reaction mechanism by UVvisible spectroscopy and mass spectrometry, J. Inorg. Biochem. 95 171-176. https://doi.org/10.1016/S0162-0134(03)00101-6

MARCHIS T, AVETTA P, FABBRI D, VISCARDI G and LAURENTI E (2011) Oxidative degradation of Remazol Turquoise Blue G 133 by soybean peroxidase. J. Inorg. Biochem. 105 (2) 321-327. https://doi. org/10.1016/j.jinorgbio.2010.11.009

MATTO M and HUSAIN Q (2007) Decolorization of direct dyes by salt fractionated turnip proteins in the presence of hydrogen peroxide and redox mediators. Chemosphere 69 (2) 338-345. https://doi.org/10.1016/j.chemosphere.2007.03.069

MELGOZA AR, CRUZ A and BUITRÓN G (2004) Anaerobic/ aerobic treatment of colorants present in textile effluents. Water Sci. Technol. 50 (2) 149-155. https://www.ncbi.nlm.nih.gov/ pubmed/15344785

MOHAN SV, PRASAD KK, RAO NC and SARMA PN (2005) Acid azo dye degradation by free and immobilized horseradish peroxidase (HRP) catalyzed process. Chemosphere 58 (8) 1097-1105. https:// doi.org/10.1016/j.chemosphere.2004.09.070

MUHAMMAD AR and ASHRAF SS (2012) Survey of recent trends in 
biochemically assisted degradation of dyes. Chem. Eng. J. 209520 530. https://doi.org/10.1016/j.cej.2012.08.015

NEVES FIG, VIEIRA MC and SILVA CLM (2012) Inactivation kinetics of peroxidase in zucchini (Cucurbita pepo L.) by heat and UV-C radiation. Innovative Food Sci. Emerging Technol. 13 158-162. https://doi.org/10.1016/j.ifset.2011.10.013

NOUREN S and NAWAZ BA (2015) Mechanistic study of degradation of basic violet 3 by citrus limon peroxidase and phytotoxicity assessment of its degradation products. Biochem. Eng. J. 95 9-19. https://doi.org/10.1016/j.bej.2014.11.021

PRATO GD and BUITRÓN G (2012) Evaluation of three reagent dosing strategies in a photo-Fenton process for the decolorization of azo dye mixtures. J. Hazardous Mater. 217-218 293-300. https:// doi.org/10.1016/j.jhazmat.2012.03.036

RAI HS, BHATTACHARYYA MS, SINGH J, BANSAL TK, VATS $P$ and BANERJEE UC (2005) Removal of dyes from the effluent of textile and dyestuff manufacturing industry: a review of emerging techniques with reference to biological treatment. Crit. Rev. Environ. Sci. Technol. 35 (3) 219-238. http://dx.doi. org/10.1080/10643380590917932

SHAFFIQU TS, ROY JJ, NAIR RA and ABRAHAM TE (2002) Degradation of textile dyes mediated by plant peroxidases. Appl. Biochem. Biotechnol. 102-103 (1-6) 315-326. http://doi. org/10.1385/ABAB:102-103:1-6:315

SILVA MC, DUARTE CA, SOUSA PMT, AMORIM PP, ARRIEL TJ and BATISTA CPM (2012) Decolorization of the phthalocyanine dye reactive blue 21 by turnip peroxidase and assessment of its oxidation products. J. Mol. Catal. B: Enzym. 77 9-14. https://doi. org/10.1016/j.molcatb.2011.12.006

SILVA MC, TORRES JA, DE SA LRV, CHAGAS PMB, FERREIRALEITAO VS and CORREA AD (2013) The use of soybean peroxidase in the decolourization of Remazol brilliant blue $\mathrm{R}$ and toxicological evaluation of its degradation products. $J$ Mol. Catal. B-Enzymatic 89 122-129. https://doi.org/10.1016/j. molcatb.2013.01.004

SRINIVASAN A and VIRARAGHAVAN T (2010) Decolorization of dye wastewater bye biosorbents: a review. J. Environ. Manage. 91 (10) 1915-1929. https://doi.org/10.1016/j.jenvman.2010.05.003

SUPAKA N, JUNTONGIN K, DAMRONGLERD S, DELIA ML and STREHAIANO P (2004) Microbial decolorization of reactive azo dyes in a sequential anaerobic-aerobic system. Chem. Eng. J. 99 (2) 169-176. https://doi.org/10.1016/j.cej.2003.09.010

VERMA AK, DASH RR and BHUNIA P (2012) A review on chemical coagulation-flocculation technologies for removal of colour from textile wastewater. Environ. Manage. 93 (1) 154-168. https://doi. org/10.1016/j.jenvman.2011.09.012

WANG H, LI P, PANG M, ZHAI ZJ, YU GL, LIU G and YAO J (2009) Rapid decolourization of azo dyes by a new isolated higher manganese peroxidase producer: Phanerochaete sp. HSD. Biochem. Eng. J. 46 (3) 327-333. https://doi.org/10.1016/j.bej.2009.06.008

WU J, BEWTRA JK, BISWAS N and TAYLOR KE (1994) Effect of $\mathrm{H}_{2} \mathrm{O}_{2}$ addition mode on enzymatic removal of phenol from wastewater in the presence of polyethylene glycol. Can. J. Chem. Eng. 72 (5) 881-886. https://doi.org/10.1002/cjce.5450720515 